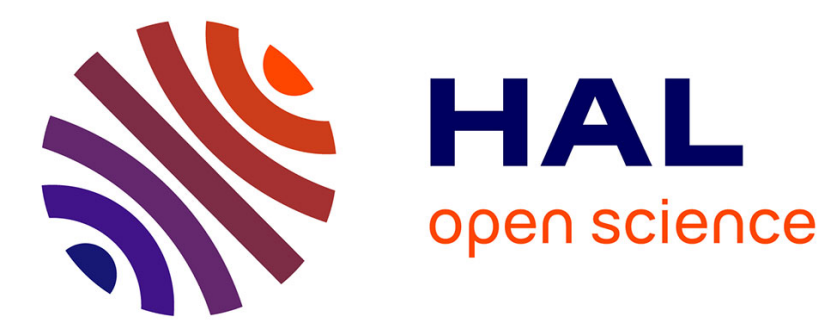

\title{
Exchange-rate Misalignments in Duopoly: The Case of Airbus and Boeing
}

Agnès Bénassy-Quéré, Lionel Fontagné, Horst Raff

\section{To cite this version:}

Agnès Bénassy-Quéré, Lionel Fontagné, Horst Raff. Exchange-rate Misalignments in Duopoly: The Case of Airbus and Boeing. The World Economy, 2011, 34 (4), pp.623-641. 10.1111/j.14679701.2011.01338.x . hal-00603386

\section{HAL Id: hal-00603386 https://hal.science/hal-00603386}

Submitted on 24 Jun 2011

HAL is a multi-disciplinary open access archive for the deposit and dissemination of scientific research documents, whether they are published or not. The documents may come from teaching and research institutions in France or abroad, or from public or private research centers.
L'archive ouverte pluridisciplinaire $\mathbf{H A L}$, est destinée au dépôt et à la diffusion de documents scientifiques de niveau recherche, publiés ou non, émanant des établissements d'enseignement et de recherche français ou étrangers, des laboratoires publics ou privés. 
This is the pre-peer reviewed version

of the article accepted for publication in The World Economy

\title{
Exchange rate Misalignments in Duopoly: The Case of Airbus and Boeing
}

\author{
Agnès Bénassy-Quéré ${ }^{1}$, Lionel Fontagné ${ }^{2}$ and Horst Raff ${ }^{3}$
}

\begin{abstract}
We examine the effect of exchange rate misalignments on competition in the market for large commercial aircraft. This market is a duopoly where players compete in dollar denominated prices while one of them, Airbus, incurs costs mostly in euros. We construct and calibrate a simulation model to investigate how companies adjust their prices to deal with the effects of a temporary misalignment, and how this affects profit margins and volumes. We also explore the effects on the long run dynamics of competition. We conclude that, due to the duopolistic nature of the aircraft market, Airbus will pass only a small part of the exchange rate fluctuations on to customers. Moreover, due to features specific to the aircraft industry, such as customer switching costs and learning by doing, even a temporary departure of the exchange rate from its long run equilibrium level may have permanent effects on the industry.
\end{abstract}

JEL Classification: F31, D43, L11, L62.

Keywords: Exchange rate pass-through, duopoly, aircraft industry.

1-CEPII, 9 rue Georges Pitard, 75015 Paris, France. Email: agnes.benassy@cepii.fr, Tel. +33 153685541.

2- Paris School of Economics, University Paris I and CEPII, Maison des Sciences Economiques, 110-112 Boulevard de l’Hôpital, 75015 Paris, France. Email: lionel.fontagne@univparis1.fr, Tel. +33 144078337.

3- Kiel Institute for the World Economy and Department of Economics, University of Kiel, 24098 Kiel, Germany. Email: raff@econtheory.unikiel.de, Tel. +49 4318801582. 


\title{
Exchange rate Misalignments in Duopoly: The Case of Airbus and Boeing
}

\author{
Agnès Bénassy-Quéré ${ }^{1}$, Lionel Fontagné ${ }^{2}$ and Horst Raff ${ }^{3}$ \\ 1-CEPII \\ 2- Paris School of Economics, University Paris I and CEPII \\ 3- Kiel Institute for the World Economy and Department of Economics, University of Kiel
}

\section{INTRODUCTION ${ }^{*}$}

This paper examines the effect of exchange-rate misalignments on competition in the market for large commercial aircraft. We focus on the aircraft industry for three reasons. First, it is a big and technologically advanced industry; changes in the market performance of this industry hence have significant effects on the economy as a whole. Second, exchange-rate misalignments have a particularly stark effect on this industry. This is due to the fact that the industry is a duopoly where prices are mostly set in dollars but one competitor, namely Airbus, has costs that are largely denominated in euros. Airbus thus bears the full brunt of euro/dollar fluctuation. In contrast, the other firm, Boeing, is almost completely protected from exchange-rate movements because its costs are mostly in dollars. Third, our estimates of price elasticities and exchange-rate pass-through indicate that market performance in the aircraft industry is quite similar to that of other equipment industries. This suggests that our results will apply, at least qualitatively, to many other industries.

While exchange-rate fluctuations have a strong impact on many industries, economists generally adopt a low profile when it comes to exchange-rate forecasting. Indeed, the empirical literature on exchange-rates has suffered a long-lasting depression since the celebrated paper by Meese and Rogoff (1983) showing that no macro-econometric model is able to outperform the simple random walk, i.e. that

\footnotetext{
${ }^{*}$ We are grateful to Matthieu Crozet for helpful remarks on a previous version of this paper. All errors remain ours.
} 
the best prediction of the exchange-rate is the present, observed rate. In the long run, however, economic theory as well as econometric techniques do succeed in providing meaningful benchmarks for equilibrium exchange rates. These benchmarks suggest that firms have to deal with long-lasting misalignments. For instance, the half-life of misalignments relative to purchasing power parity (PPP) is thought to be around 4-5 years (Rogoff, 1995) ${ }^{1}$. Consider, for example, German companies. As shown in Figure 1, these companies often have to deal with $20-30 \%$ deviations from PPP that can last several years.

Derivative markets offer extensive hedging instruments against exchange-rate fluctuations. However, the bulk of the market concentrates on relatively short horizons of up to one year. In April 2007, over-the-counter contracts exceeding one year only represented $1.1 \%$ of the turnover for euro-dollar outward forwards, and $0.6 \%$ of foreign exchange swaps (BIS, 2007). This time horizon is too short to provide protection for exchange-rate misalignments. Longer-term or rolling hedging contracts are exceedingly costly, so hedging does not solve the exchange-rate problem of firms.

-- Figure 1 about here --

The aircraft industry provides a good example of how hard firms may be hit by exchange-rate movements. To quantify this impact we construct a simple simulation model of the Airbus-Boeing duopoly. In particular, we use this model to examine how companies adjust their prices to deal with the effects of a temporary misalignment, and how this affects profit margins and volumes and, ultimately, the dynamics of competition.

The main results of our analysis are as follows. First, for realistic values of price and cross-price elasticities, exchange rate misalignments have strong impacts especially on profit margins. By adjusting its price-cost margins, Airbus will manage to only slightly limit the impact of exchange-rate variations on its profits. In our central scenario, Airbus is likely to absorb most of exchange-rate movements rather than pass them on to customers. Still, its operating profits in dollars are reduced by more than $40 \%$ while

\footnotetext{
${ }^{1}$ Half-lives are found to be shorter when using a Behavioral-Equilibrium-Exchange Rate approach à la Faruque (1995) and MacDonald (1997). But they are still several years long.
} 
output is reduced by one fourth in case of a $10 \%$ appreciation of the euro against the dollar. Second, even short-run misalignments may have significant long-term consequences due to several features of the aircraft market, including customer switching costs and learning effects in production.

The paper is organized as follows. In Section 2 we characterize the market structure and provide price elasticities coefficients for the aircraft industry. In Section 3 we report the results of our simulation model concerning the effects of exchange-rate changes on prices, outputs and operating profits in the aircraft industry. Section 4 concludes. The Appendix contains details of the simulation model.

\section{THE STRUCTURE OF THE AIRCRAFT MARKET}

In this section we study the aircraft industry in detail at the product, market segment and destination market level, and by exporter in order to identify the idiosyncrasies of this sector and its sensitivity to cost and price changes. For this purpose, we use the database BACI constructed by the CEPII, which provides bilateral flows as well as unit values for 5,000 products being traded between more than 200 countries, from 1994 to $2004 .^{2}$

\section{a. Major Exporters}

The aircraft industry is highly concentrated at both the firm and the country level. At the firm level we have a duopoly (for the major segments of the market) or a highly concentrated oligopoly (for the remaining products). At the country level, only a few exporting countries account for the bulk of world-wide production. Table 1 presents the market shares of France, Germany, the United States and other potential competitors in the non-EU market for "big aircraft". ${ }^{3}$

\footnotetext{
${ }^{2}$ See www.cepii.fr/anglaisgraph/bdd/baci.htm. BACI draws on United Nations COMTRADE trade data base. We are indebted to Rodrigo Paillacar for his research assistance with BACI.

${ }^{3}$ We use the words "big aircraft" for designing airliners classified under item 880240 of the HS6. This corresponds to aircraft of an unloaded weight exceeding 15,000 kg. For sake of comparison, an Airbus A318 has an unloaded weight of 39,800kg and a Boeing 737-100 26,181 kg. To the extent that Airbus has a higher market share than Boeing on the European market, excluding UE25 imports leads to downsizing European market shares in this Table.
} 
We observe a clear pattern of duopoly, provided that Airbus aircraft can be exported either from France or from Germany. On OECD markets, the market shares of the duopolists vary quite substantially over time, without exhibiting a clear pattern. By contrast, Boeing is clearly losing market shares on emerging markets. This is not to the benefit of Airbus only, since the competitive fringe, represented here by Russia, managed to reap six percent of the emerging markets during the last period considered here. Other potential competitors from the emerging world include Brazil (on OECD markets only) and China. ${ }^{4}$

\section{b. Price elasticities and exchange-rate pass-through}

The impact of exchange-rate variations on sales and profits crucially depends on two parameters: (i) the price elasticity of demand, which determines how sales will react to price variations; (ii) and the pass-through coefficient, which determines how cost-push shocks (here, an appreciation of the domestic currency) will be passed on the customers.

Here, we rely on price elasticities estimated at the HS6 level for 21 distinct markets for the 1994-2003 period. $^{5}$ The estimation technique is derived from Feenstra (1994), and Broda and Weinstein (2004). ${ }^{6}$ Trade volumes and unit values are provided by the BACI database. ${ }^{7}$ Estimated elasticities are aggregated using trade weights.

\footnotetext{
${ }^{4}$ The position HS880240 comprises new as well as used or rebuilt aircraft. For this reason, some marginal exporters appear in the data. The overall picture is only marginally affected however. Importantly, it must be stressed that for certain segments of the market - such as the Airbus 320 - used or rebuilt aircraft are actually good substitutes to new aircraft for the airline companies. This reinforces the already tough competition on the corresponding market segments. The (non zero) 10-digit US tariff lines classified under the HS6 position 880240 correspond to: new aircraft non military for passengers ( $78 \%$ of the exported value in 2004), new aircraft non military cargo (11\%), new military cargo (2\%) and used or rebuilt aircraft non military ( $9 \%)$.

${ }^{5}$ 1995-2003 for Belgium, 1996-2003 for Russia and 1994-2002 for Canada.

${ }^{6}$ See Gaulier and Méjean (2006). Feenstra uses a reduced form of a model of import demand and supply where varieties are defined on the basis of the exporting country, while goods are identified at the most disaggregated level of the product classification. The model relies on the classical CES framework, and the estimation takes benefit of the cross-country variance in the data. We thank Isabelle Méjean and Julien Martin for their advice and assistance.
} 
If we concentrate on the core market segment of Airbus and Boeing — big aircraft — we find relatively standard elasticities on most OECD markets: a 1 percent price increase leads to a 2 to 6 percent reduction in the volume of sales (Table 2). Although comparable to other sectors of professional equipment, these elasticities mean that a 10 percent appreciation of the euro, if completely passed on to export prices, would reduce Airbus sales by 20 to 60 percent in volume and 10 to 50 percent in euro-denominated value, which is obviously very large. ${ }^{8}$ Furthermore, price elasticities are found to be even larger in emerging markets: estimated elasticities exceed 10 in Mexico and Brazil, and they are found to be even higher in Russia, India, and China. However, these very high figures may well be over-stated, because on these new markets, volume growth is very high and may be spuriously attributed to price variations, especially since the time-span is limited. In the next section, we retain price elasticities ranging from 2 to 8 , which corresponds to mature markets.

These high price elasticities imply that exchange rate variations have potentially strong effects. This is because a high elasticity leads to a large reaction of demand to price changes. Still, it also means limited price-cost margins, and hence limited capacity to dig into the margins to finance limited pass-trough in case of a home-currency appreciation. This is all the more the case on emerging markets, where new fleets are being set up, or where airlines have the choice to resort to the second-hand market.

\section{-- Table 2 about here --}

In order for exchange-rate variations to be completely passed through into prices of imported goods, export prices (expressed in the exporter's currency) must not react to currency changes. However,

\footnotetext{
Note that this method assumes that estimated elasticities are good-specific and not exporter-specific, which is acceptable in our case.

${ }^{7}$ Note that unit values are not equivalent to genuine price series. However, genuine prices are not available at this level of detail, so one has to rely on unit values.

${ }^{8}$ For instance, considering the US market, the elasticity is 8.5 for "Instantaneous gas water heaters", 5.0 for "Cylinders for calendering or rolling machines, excluding for metals or glass", and 4.6 for "Medical, surgical or laboratory sterilizers".
} 
producers may absorb part of the exchange-rate variation in which case there will be incomplete pass-through.

Denoting by $P_{i j t}$ the price of aircraft sold by country $i$ on market $j$ at time $t$ (denominated in $i$ 's currency), by $\operatorname{COST}_{i t}$ the marginal cost of producing aircraft, by $S_{i j t}$ the bilateral real exchange-rate (a fall in $S_{i j t}$ denotes an appreciation of $i$ 's currency), and by $Z_{j t}$ the importer's specific features of sectoral demand at year $t$, one should simply regress:

$$
d \ln P_{i j t}=a_{i j} d \ln C O S T_{i t}+b_{i j} d \ln S_{i j t}+c_{i j} d \ln Z_{j t}+u_{i j t}
$$

The parameter estimate obtained for the exchange-rate $\left(b_{i j}\right)$ is the elasticity of export prices to currency changes: $b_{i j}$ is the pricing-to-market coefficient, and $\left(1-b_{i j}\right)$ is the pass-through coefficient. For instance, if $b_{i j}=0$ (or not significantly different from zero), then the producers of country $i$ do not change their export prices in their own currency following an exchange-rate appreciation. This means that the price in the target market's currency are increased in the same proportion as the exchange rate-appreciation: there is full pass-through of the exchange-rate appreciation (no pricing to market).

At the other extreme, if $b_{i j}=1$, then export prices in the exporter's currency are reduced by 1 percent whenever the exchange-rate appreciates by 1 percent. In this case, prices in the importer's currency are not affected by exchange-rate variations: there is no pass-through, and exchange-rate variations are fully absorbed by the exporter's margins.

According to Gaulier et al. (2006) using HS6 level data for 130 countries over the 1989-2003 period, the median estimate of $b_{i j}$ is 0.14 , meaning that, for the median product-exporter-importer, a 10 percent appreciation will result in a 1.4 percent reduction in the export price expressed in the exporter's currency, i.e., in a 8.6 percent increase in the export price expressed in the importer's currency. Unfortunately, for the aircraft industry, the empirical results found are highly volatile and unreliable, due to the long delays between orders and deliveries. This led us to finally derive optimal pass-through 
coefficients from profit maximization given different values of price elasticities (in line with the above estimations) and accounting for the oligopolistic structure of the market.

\section{COMPETITION AND EXCHANGE-RATE VARIATION}

In this section we examine the consequences of a (temporary) depreciation of the U.S. dollar against the euro for the competition in the aircraft industry. There are two ways to proceed. From a euro perspective, the dollar depreciation implies a reduction in Airbus's revenues in euros. From a dollar perspective, the depreciation leaves revenues unchanged but raises Airbus's costs. For our analysis it turns out to be convenient to adopt the second perspective: Airbus and Boeing compete in dollars, and Airbus faces an increase in its production costs.

Isolating the true effect of the dollar weakness on Airbus is a challenging task for two reasons. First, one has to estimate the effect of factors unrelated to the exchange-rate. Second, one has to estimate what the both Airbus and Boeing adjust their corporate strategies to changes in the exchange-rate. The dollar depreciation, in other words, alters the structure of competition in the market. We hence set up a simulation model of the aircraft market that helps us evaluate the exchange-rate effect on the market equilibrium.

We develop our arguments in two steps. In a first step, we examine the market under the assumption that the exchange-rate shock is permanent and hence causes permanent shifts in pricing strategies, market shares and profits. This scenario provides us with a simple benchmark against which we can compare the effects of temporary exchange-rate shocks. Examining such temporary shocks and their effects on inter-temporal pricing strategies and market adjustments constitutes the second step. Throughout both steps we assume that Airbus and Boeing are in a stable duopoly in which no company leaves the market and there is no threat of entry by new rivals. Competition takes place in prices. That prices are the main competitive instrument in the aircraft industry is also suggested by the apparently 
widespread use of price discounts and generous financing options for airlines (Irwin and Pavcnik, 2004). We hence concentrate our analysis on changes in price competition between Airbus and Boeing.

\section{a. Benchmark: permanent exchange-rate shocks}

Consider a permanent dollar depreciation that raises Airbus's production cost relative to Boeing's. If Airbus did not have to worry about competition from Boeing it would optimally react to an increase in its production costs by raising the prices of its products so as to pass on part of the cost increase to its customers.

The decision-making problem for Airbus is obviously more challenging, since Boeing will adjust its own prices in response to Airbus's price changes. Any price change by Airbus affects demand for Boeing aircraft and vice versa. With a positive cross-price elasticity, any price change by Airbus triggers a reaction by Boeing. Specifically, Airbus can expect its rival to follow suit with a price increase but not to raise prices by the same percentage. In other words, Airbus should expect to lose some market share to Boeing.

To illustrate the effects of the dollar depreciation, we construct a simple duopoly model of the market for Airbus's A320 aircraft family and Boeing's 737. This model allows us to simulate the effects of exchange-rate changes on the prices, outputs and operating profits of the A320/B737 segment, based on profit-maximizing producers. See the Appendix for details of the model.

We simulate the effects of a $10 \%$ appreciation of the euro against the dollar on the prices, outputs and operating profits of Airbus and Boeing. Table 3 reports the percentage changes in prices, outputs and operating profits for different values of the price elasticity of demand and the cross-price elasticity of demand. ${ }^{9}$ These values are computed assuming that all of Airbus's costs are in euro. If, for example, only

\footnotetext{
${ }^{9}$ The reported values of the elasticities are used to calibrate the parameters of the demand functions in the initial equilibrium. In the simulations we hold the demand parameters constant, but allow elasticities to change. See the Appendix for details of the calibration procedure.
} 
$80 \%$ of costs are in euro and the rest in dollar, then the changes in prices and outputs are only $80 \%$ of those reported in the table.

In the base case (in bold in Table 3), we use a price elasticity of 6 and a cross-price elasticity of 1.5. In this scenario, demand is very sensitive to changes in one's own price. However, demand is not very sensitive to changes in the competitor's price. Correspondingly, price adjustments by Airbus have a strong effect on its own output and operating profit, but weak effects on Boeing's output and operating profit. The results are reported in Column 4 of Table 3: a 10\% appreciation of the euro (equivalent to a $10 \%$ increase in Airbus's dollar-denominated marginal cost) implies that the dollar price of an A320 family aircraft rises by $4.2 \%$. That is, it is a profit-maximizing strategy for Airbus to pass less than half the exchange rate-induced cost increase on to customers. Boeing raises the price of its 737 , too, namely by $0.5 \%$. The small magnitude of Boeing's price adjustment is due to the small cross-price elasticity of demand in this benchmark scenario.

-- Table 3 about here --

The price changes have strong effects on output. Sales of A320 family aircraft fall by $24.6 \%$, whereas sales of $737 \mathrm{~s}$ increase by $3.2 \%$. Airbus's operating profits for this aircraft family decrease by $43 \%$, those of Boeing go up by $6.5 \%$. The profit-maximizing adjustment to the exchange-rate movement can be contrasted with the change in operating profit if Airbus did not adjust its price. In the absence of dollar-price changes output remains constant. The decrease in operating profit therefore reflects only the increase in production costs. The result is reported in the last line of Table 3. For the base case, the operating profit without price adjustment falls by $50 \%$.

The price and output effects of the dollar depreciation depend crucially on the capacity of Airbus to absorb part of the shock and preserve its sales, and on the reaction of Boeing to the change in the price of its competitor. The first issue relates to the price-cost margin of Airbus: a larger price-cost margin leaves more room for adjustment. It turns out that the price-cost margin is determined only by the price elasticity of demand since the number of competitors is fixed by assumption. In other words, the larger the 
own-price elasticity of demand, the smaller the price-cost margin and the lower the room for cutting margins to preserve volumes. Hence the higher the own-price elasticities, the higher the incentive to pass on the exchange-rate shock to the consumer. The second issue relates to cross-price elasticities of demand. The larger these cross-price elasticities, the larger the shift of demand from Airbus to Boeing for a given price increase by Airbus. Thus, the larger these cross-price elasticities, the more Boeing will be in position to increase its price as a reaction to Airbus own price increase.

As an illustration we can check in Table 3 that reducing the price elasticity to 4 (leaving the cross-price elasticity unchanged at 1.5 ), implies that a $10 \%$ increase in the dollar-denominated marginal cost triggers a smaller price increase by Airbus (3.9\% instead of 4.2\%). Airbus's output drops much less (by 14.5\%). As far as the decline in Airbus's operating profit is concerned, the right comparison to be made is with the benchmark case without price adjustment. With a price elasticity of 6 , the price adjustment allows Airbus to salvage 7 percentage points of profits (i.e., profits decrease by $43 \%$ compared to a $50 \%$ loss otherwise). With a less elastic demand, Airbus can afford to salvage only 3.2 points of its profits; we should indeed keep in mind that these figures apply to different amounts of profits in both cases.

The last two columns of Table 3 examine the effect of changes in the cross-price elasticity starting from the base case reported in Column 4. Raising the cross-price elasticity from 1.5 to 3 implies that a price increase by Airbus shifts more demand to Boeing. This allows Boeing to raise its price while significantly raising its output and operating profit. The stronger price increase by Boeing dampens the effect of the euro appreciation on Airbus's output and operating profit.

To summarize, the depreciation of the dollar forces Airbus to raise prices and cede market share to Boeing. The scope for price increases is determined by the price-cost margin of Airbus, namely its capacity to absorb the shock and preserve its sales. How strong Boeing's price reaction is and how much it benefits from Airbus's price increase depends on the cross-price elasticity of demand. If it is large, any price increase by Airbus will shift a large amount of sales to Boeing. The latter firm will accordingly raise 
its price by more and still gain considerable market share at the expense of Airbus, leading to a strong increase in Boeing's operating profit.

\section{b. Permanent effects of temporary exchange rate shocks}

An analysis in terms of equilibrium exchange-rates suggests that major exchange-rate misalignments may only be temporary. However, even temporary exchange-rate shocks are likely to have long-term effects on prices, outputs and profits. This is due to several features of the aircraft market that imply that today's pricing decisions affect future market shares and hence also future prices. Pricing decisions, in other words, are inter-temporally linked, and Airbus has to take this into account when deciding how to adjust to a shock on the dollar exchange-rate. Our analysis in the previous section has to be modified to account for this fact. ${ }^{10}$

There are at least two features of the aircraft market that induce an inter-temporal link in pricing decisions: switching costs on the demand side and learning effects on the supply side.

First, some customers face considerable costs when switching between alternative aircraft suppliers. Among the reasons for this are that there are considerable costs involved in retraining pilots, crew, and maintenance personnel when purchasing aircraft from a different producer. Airlines operating aircraft from a single manufacturer, on the other hand, enjoy considerable advantages of commonality. Switching costs imply that a firm that attracts customers today will have a larger demand base in the future. Symmetrically, a firm losing customers today because of high prices may have a hard time winning them back in the future unless it sharply reduces its price. Switching costs are accordingly a key determinant of the price and cross-price elasticities of demand. The more existing customers are locked into Airbus products, the less sensitive they are to price increases and the less likely they are to switch to Boeing. Both

\footnotetext{
${ }^{10}$ Seminal papers investigating the effect of inter-temporal pricing decisions on exchange-rate pass-through include Baldwin (1988), and Froot and Klemperer (1989). An empirical study of pass-through in a dynamic oligopoly —in this case the Swiss automobile market—is provided by Gross and Schmitt (2000).
} 
the price and cross-price elasticities of these customers are likely to be small. Hence there is an incentive to charge these customers high prices.

The story is different for new customers that have not yet made a choice between Airbus and Boeing. These customers will anticipate that in future they will face switching costs and possibly rising prices for services and replacement aircraft. They will therefore be quite sensitive to current prices. That is, their price and cross-price elasticities will be high. Airbus and Boeing both face an incentive to offer low prices to attract these customers. Our data analysis in the previous section revealed striking differences in price elasticities across regions, with elasticities typically being much higher in emerging markets, such as China and India, than in the industrialized countries. Such differences would be consistent with a higher ratio of new to existing customers in emerging markets compared to industrialized countries. If this is indeed the case, Airbus may be able at least indirectly to price discriminate between new and old customers, namely by offering customers in emerging markets more favorable terms during the phase of over-evaluation of the euro.

A second argument linking short term decisions and long term impacts relies on the learning curve. The production especially of new aircraft generates significant learning effects. Some estimates of the learning elasticity for newly developed aircraft are as high as 0.2 , meaning that a doubling of output reduces costs by $20 \%$ (see Klepper, 1990). A recent study by Benkard (2004) suggests that a doubling of cumulated experience leads to a $36 \%$ reduction in labor input requirements. ${ }^{11}$ In the presence of learning-by-doing, a price increase reduces output, thereby slowing down the learning process. Slower learning means greater production costs in the future. These inflated production costs, in turn, imply higher future prices and a smaller market share. Price increases today are therefore self-propagating. Reacting to a temporary exchange-rate shock by raising prices would lead to a permanent loss of market share to Boeing.

\footnotetext{
${ }^{11}$ In the case of Airbus, such learning effects are probably very strong in the case of the A380 and A350. They are likely to be weak in the case of long-established products like the A320 family.
} 
When this second argument is taken into account, the link between today's prices and future market share generates a trade-off between current and future profits. Airbus can respond to an adverse temporary exchange-rate shock by raising prices in foreign currency to maximize current profits. This, however, tends to lower future profits, because high prices today reduce future market share and/or lead to higher future production costs. Alternatively, Airbus can give up current profit by keeping prices lower. This raises future market share and/or lowers future costs, thereby driving up future profits. Two considerations determine the optimal inter-temporal trade-off. The first is by how much future earnings are discounted relative to current ones. This is a question of which discount rate is used to compute the present value of the company's expected profit stream. The second consideration concerns the expected movement of the exchange-rate. A temporary dollar depreciation followed by an appreciation decreases the euro value of today's profits relatively to the euro value of future profits. Hence there is an incentive to keep prices and profit margins lower today to raise future profits.

The two arguments are not independent however. Incidentally, it is exactly the new products where learning-by-doing is important that should exhibit large price elasticities due to the fact that customers will anticipate future switching costs. For example, an airline purchasing the A380 rather than Boeing's 787 thereby commits to a hub-and-spoke system rather than a system supporting a larger number of direct, smaller-volume connections between airports. Hence there are two interrelated reasons why Airbus may choose to keep prices for such products low despite a temporary shock to production costs, namely to facilitate learning and to compete for customers that will then be locked into the product.

The bottom line of this section is that even temporary exchange-rate shocks tend to have permanent effects on prices, market shares and operating profits in the presence of switching costs and learning-by-doing. Airbus may react to a temporary depreciation of the dollar followed by a medium-term appreciation by raising prices less than indicated by short-run profit maximization. By keeping prices low today, Airbus can secure a higher future market share and then benefit from a future appreciation of the 
dollar. The optimal trade-off between lower current and higher future profits depends on the discount rate and exchange rate expectations.

\section{CONCLUSION}

Exchange-rates are known to be very volatile. Furthermore, departures of the exchange-rate from "long-run equilibrium" are generally long-lived. This translates into major cost shocks for those companies suffering from a currency mismatch between revenue and cost. In this paper, we studied the implications of large, although temporary, deviations of the exchange rate in a duopoly case where one company suffers from such a currency mismatch.

First, price-elasticities of aircraft exports at the detailed level are used to calibrate a simple, static model of optimal pricing in the Airbus-Boeing duopoly. The aircraft industry is perfectly suited for this exercise because it perfectly fits the scenario where one firm suffers from a currency mismatch. We showed that the best response to a cost-push appreciation of the home currency is to contract current profits by limiting the pass-through to export prices to less than $50 \%$. The rationale behind this strategy is that any rise in one firm's price leads to an important contraction of its sales. This strategy is even reinforced when the temporary character of the exchange rate shock is accounted for. This is because customers face switching costs when they move from one supplier to the other, and because the production of an aircraft exhibits significant learning effects. Sacrificing current profits allows a firm to maintain its market share, hence to continue to enjoy learning economies while attracting new customers. In the next period, when the exchange rate comes back to its "long-run equilibrium" value, the firm will enjoy lower costs (due to learning economies) as well as higher demand (thanks to new customers being locked in), compared to a strategy of high pass-through of the exchange rate shock. This is all the more important since the dynamics of the market are driven by new air-line companies, especially in emerging countries, whose decisions today will have long-lasting effects. 
Still, the inter-temporal strategy of sacrificing current profit in exchange for higher future profits is very risky, since it is hard to predict how long an exchange rate misalignment may last. Two additional factors tend to increase the risk. First, a potential problem of compressing margins today is that it may make it more difficult to finance R\&D spending, specifically the development of new products. This weakness may be used by the competitor to speed up its own R\&D. Hence, a trade-off needs to be made between the "current-business" view that urges not to pass exchange rate appreciation on to export prices, and the "innovation" view that stresses the needs to maintain the R\&D capacity of the firm over the exchange rate cycle. In principle, the financial market should help to alleviate this trade-off.

Second, a misalignment raises the likelihood that a new producer may enter the market, if the exchange rate shock leads the incumbent firms to raise prices. Higher market prices for aircraft make entry, for instance by China, more profitable. The threat of entry strengthens the case for little exchange rate pass-through in the short and medium term, provided that this helps deter entry. However, if entry cannot be deterred, short-and medium-term pass-through should be higher, because future profits are reduced by entry. 


\section{APPENDIX 1: THE SIMULATION MODEL}

Competition between Airbus (firm $A$ ) and Boeing (firm $B$ ) is modelled as a linear price competition game between the A320 family and Boeing's 737. These aircraft are treated as differentiated products with symmetric price and cross-price elasticities of demand. The demand functions are given by:

$$
\begin{aligned}
& x_{A}=\alpha_{A}-\beta_{A} p_{A}+\gamma_{A} p_{B} \\
& x_{B}=\alpha_{B}-\beta_{B} p_{B}+\gamma_{B} p_{A}
\end{aligned}
$$

The demand parameters $\alpha_{i}, \beta_{i}$ and $\gamma_{i}, i=A, B$, are assumed positive and constant, so that demand for each product is decreasing in its own price and increasing in the price of the competing good.

The operating profits are:

$$
\begin{aligned}
& \pi_{A}=\left(p_{A}-\theta c_{A}\right)\left(\alpha_{A}-\beta_{A} p_{A}+\gamma_{A} p_{B}\right) \\
& \pi_{B}=\left(p_{B}-c_{B}\right)\left(\alpha_{B}-\beta_{B} p_{B}+\gamma_{B} p_{A}\right)
\end{aligned}
$$

where $\theta$ is a shock on the euro/dollar exchange-rate, $c_{A}$ and $c_{B}$ denote Airbus's and Boeing's marginal costs in euros and dollars, respectively. Initially, $\theta$ is set to unity so that $\theta c_{A}=c_{A}$. Then, an appreciation of the euro against the dollar translates into higher marginal cost for Airbus $\left(\theta c_{A}>c_{A}\right)$ whereas the marginal cost of Boeing remains constant at $c_{B}$.

Taking the derivative of each profit function with respect to the own price yields the firms' best-response functions. From these best responses we can compute the following equilibrium prices:

$$
\begin{aligned}
& p_{A}=\frac{2 \alpha_{A} \beta_{B}+\gamma_{A} \alpha_{B}+\gamma_{A} \beta_{B} c_{B}+2 \beta_{A} \theta c_{A} \beta_{B}}{4 \beta_{B} \beta_{A}-\gamma_{A} \gamma_{B}} \\
& p_{B}=\frac{2 \alpha_{B} \beta_{A}+\gamma_{B} \alpha_{A}+\gamma_{B} \beta_{A} \theta c_{A}+2 \beta_{B} c_{B} \beta_{A}}{4 \beta_{B} \beta_{A}-\gamma_{A} \gamma_{B}}
\end{aligned}
$$

Using (6) and (7) in (2) and (3), as well as in (4) and (5) yields equilibrium outputs and operating profits. 


\section{APPENDIX 2: THE CALIBRATION}

The model is calibrated using the actual 2006 deliveries of A320 family and 737 aircraft and estimated 2006 unit prices denominated in dollar. In 2006, Airbus delivered 339 aircraft in this segment, whereas Boeing produced 302 aircraft. Data on actual prices are not available. A rough estimate of the unit price is $\$ 60 \mathrm{~m}$ for both Airbus and Boeing. ${ }^{12}$ Specifically we calibrate the demand parameters $\alpha_{i}, \beta_{i}$ and $\gamma_{i}$, and the marginal costs $c_{i}, i=A, B$, to fit the assumed quantities and prices, namely $x_{A}=339, x_{B}=$ $302, p_{A}=60000000$ and $p_{B}=60000000$. To see how this is done, consider, for example, parameter $\beta_{A}$. Denoting by $\varepsilon_{A}$ the own-price elasticity of demand for $A$, we have $\varepsilon_{A}=\beta_{A} p_{A} / x_{A}$. From this we can compute $\beta_{A}$ for the different values of $\varepsilon_{A}$ reported in Table 4 . The same procedure applies to the other parameters of the demand functions, which we compute using the reported price and cross-price elasticities of demand. In the simulation we hold the demand parameters constant. ${ }^{13}$

Estimates of price and cross-price elasticities in the aircraft market are drawn from Section 2.2 and from Irwin and Pavcnik (2004). For the period 1994-1998, the latter report a price elasticity for wide-body aircraft of just under 8. Additionally, Irwin and Pavcnik report cross-price elasticity values of around 1.5. Using trade data at the HS6 level, we found price-elasticities for mature markets of "big airplanes" ranging from 2 to 6 , which is lower than the estimate by Irwin and Pavcnik. The latter, too, find the price elasticity for narrow-body aircraft like the A320 to be smaller than 8. Moreover, due to increased market concentration following the merger between Boeing and McDonnell Douglas in 1997, the market has become more concentrated. A price elasticity of 8 hence appears excessive. In our basic scenario we therefore assume a price elasticity of 6 . As a robustness check, we also simulate results for higher and lower values of the elasticity.

\footnotetext{
${ }^{12}$ Quantity data are taken from the companies' annual reports. Prices are rough estimates based on industry reports.

${ }^{13}$ Note that the values of the price and cross-price elasticities that are used to compute the demand parameters apply only around the initial equilibrium. Due to the linearity of the demand functions, the elasticities change as prices rise or fall. For instance, a constant $\beta_{A}$ translates into an increasing $\varepsilon_{A}$ when the price increases. This implies that a price increase tends to lower the mark-up, leading to incomplete pass-through.
} 
Since Airbus and Boeing have multiple product lines, they can be expected to co-ordinate price adjustments across these lines. For example, when setting its price for the A320, Airbus should take into account that a unilateral increase in price may induce customers to shift demand not just to Boeing but also to Airbus's own A330/340 family. However, the cross-price elasticities across product lines reported by Irwin and Pavcnik are very close to zero. We therefore set them to zero in our simulation.

Production cost data are not available. We therefore infer marginal production costs from prices and elasticities. The marginal cost, i.e., the cost of producing one more aircraft, is assumed to be constant up to the capacity limit. This is consistent with the fact that the A320 and B737 are established products with little potential for learning-by-doing. Marginal costs are computed using the Lerner condition: $c_{i}=p_{i}\left(1-\frac{1}{\varepsilon_{i}}\right), i=A, B$, where $\varepsilon_{i}$ represents the price elasticity of demand. Finally, the $\alpha_{\mathrm{i}}$ are set so that the right-hand sides of (6) and (7) match the assumed 2006 prices for $\theta=1$. 


\section{APPENDIX 3: THE SIMULATION}

Using the calibrated cost and demand parameters we can now carry out simulations to compute the impact of an exchange rate shock on prices, quantities and operating profits. This is done by using different values of $\theta$ in the Nash equilibrium price equations and the computing the respective outputs and profits. We examine the robustness of these results by using different values for price and cross-price elasticities.

The simulation is carried out by computing the aircraft prices of Airbus and Boeing in the Nash equilibrium for different values of the exchange rate. These prices maximize each firm's respective profit given the rival's price. Given these prices, we can calculate outputs and profit margins. The linearity of the model has the convenient feature that exchange rate effects on Nash equilibrium prices and corresponding outputs are also linear. That is, a $20 \%$ appreciation of the euro against the dollar has twice the effect on prices and output as a $10 \%$ appreciation. Effects on operating profits, defined as the excess of price over marginal cost times output, are quadratic. A $20 \%$ appreciation of the euro therefore has less than twice the effect on Airbus's operating profit as a $10 \%$ appreciation. Conversely, the same $20 \%$ appreciation of the euro has more than twice the effect on Boeing's operating profit as a $10 \%$ appreciation. 


\section{REFERENCES}

Baldwin, R. (1988), 'Hysteresis in import prices: the beachhead effect', American Economic Review, 78, 773-785.

Baldwin, R. and P. Krugman (1989), 'Persistent Trade Effects of Large Exchange Rate Shocks', Quarterly Journal of Economics, 104, 4, 635-54.

Benkard, L. (2004), 'A dynamic analysis of the market for wide-bodied commercial aircraft', Review of Economic Studies, 71, 581-611.

Broda, C. and D. Weinstein (2004), 'Variety Growth and World Welfare', American Economic Review, 94, 2, 139-144.

Broda, C. and D. Weinstein (2005), 'Globalization and the Gains from Variety', NBER Working paper, 10314 .

Faruqee, H. (1995), 'Long-Run Determinants of the Real Exchange Rate: a Stock-Flow Perspective', IMF Staff Papers, 42, 1, 80-107.

Feenstra, R.C. (1994), 'New Product Varieties and the Measurement of International Prices', American Economic Review, 84, 1, 157-177.

Froot, K. and P. Klemperer (1989), 'Exchange rate pass-through when market share matters', American Economic Review, 79, 637-654.

Gaulier, G. and I. Méjean (2006), 'Import Prices, Variety and the Extensive Margin of Trade', CEPII Working paper, 2006-17.

Gaulier, G., I. Méjean and A. Lahrèche-Révil (2006), 'Exchange Rate Pass-Through at the Product Level', CEPII Working paper, 2006-02.

Gross, D. and N. Schmitt (2000), 'Exchange Rate Pass-Through and Dynamic Oligopoly: an Empirical Investigation', Journal of International Economics, 52, 89-112. 
Irwin, D. A. and N. Pavcnik (2004), 'Airbus versus Boeing Revisited: International Competition in the Aircraft Market', Journal of International Economics, 64, 223-245.

Klepper, G. (1990), 'Entry into the Market for Large Transport Aircraft', European Economic Review, 34, 775-803.

MacDonald, R. (1997), 'What Determines the Real Exchange Rate? The Long and the Short of it", IMF Working Paper, 97/21.

Meese, R.A. and K. Rogoff (1983), 'Empirical Models of the Seventies : do they Fit out of Sample?', Journal of International Economics, 14, 3-243.

Rogoff, K. (1996), 'The Purchasing Power Parity Puzzle', Journal of Economic Literature, 34, $647-668$ 
TABLE 1

Exporter market shares for big aircraft, by market

\begin{tabular}{|c|c|c|c|c|c|c|}
\hline \multirow{2}{*}{$\begin{array}{l}\text { Market } \\
\text { Exporter }\end{array}$} & \multicolumn{3}{|c|}{ Non-EU25 OECD markets } & \multicolumn{3}{|c|}{ Emerging markets } \\
\hline & 1995-1996 & $1999-2000$ & 2003-2004 & $1995-1996$ & $1999-2000$ & 2003-20004 \\
\hline France & 29.4 & 21.4 & 25.0 & 36.2 & 31.4 & 26.9 \\
\hline Germany & 7.2 & 12.0 & 9.9 & 0.2 & 5.5 & 15.8 \\
\hline United Kingdom & 2.2 & 1.2 & 0.0 & 0.0 & 0.1 & 0.2 \\
\hline Spain & 1.5 & 0.8 & 1.5 & 1.2 & 0.3 & 1.3 \\
\hline USA & 43.7 & 48.6 & 43.2 & 52.9 & 55.9 & 41.7 \\
\hline Canada & 0.7 & 2.7 & 6.6 & 0.5 & 0.3 & 0.7 \\
\hline Japan & 0.1 & 0.0 & 0.0 & 0.0 & 0.0 & 0.0 \\
\hline Other OECD & 9.9 & 8.3 & 8.4 & 5.5 & 4.4 & 5.5 \\
\hline Mexico & 0.7 & 0.2 & 0.0 & 0.0 & 0.0 & 0.0 \\
\hline Brazil & 0.2 & 1.0 & 1.9 & 0.0 & 0.0 & 0.0 \\
\hline China & 0.2 & 0.1 & 0.1 & 0.0 & 0.1 & 0.2 \\
\hline India & 0.0 & 0.0 & 0.0 & 0.0 & 0.0 & 0.0 \\
\hline Russia & 0.2 & 0.1 & 1.3 & 0.2 & 0.0 & 6.5 \\
\hline Other emerging & 3.1 & 2.0 & 1.0 & 2.9 & 1.5 & 0.7 \\
\hline Rest of world & 0.9 & 1.6 & 1.1 & 0.3 & 0.7 & 0.6 \\
\hline Total & 100 & 100 & 100 & 100 & 100 & 100 \\
\hline
\end{tabular}

Note: under "big aircraft" are grouped airliners under item 880240 of the HS6.

Source: BACI-CEPII, authors' calculations. 


\section{FIGURE 1}

Observed and PPP exchange rate against the USD: Germany

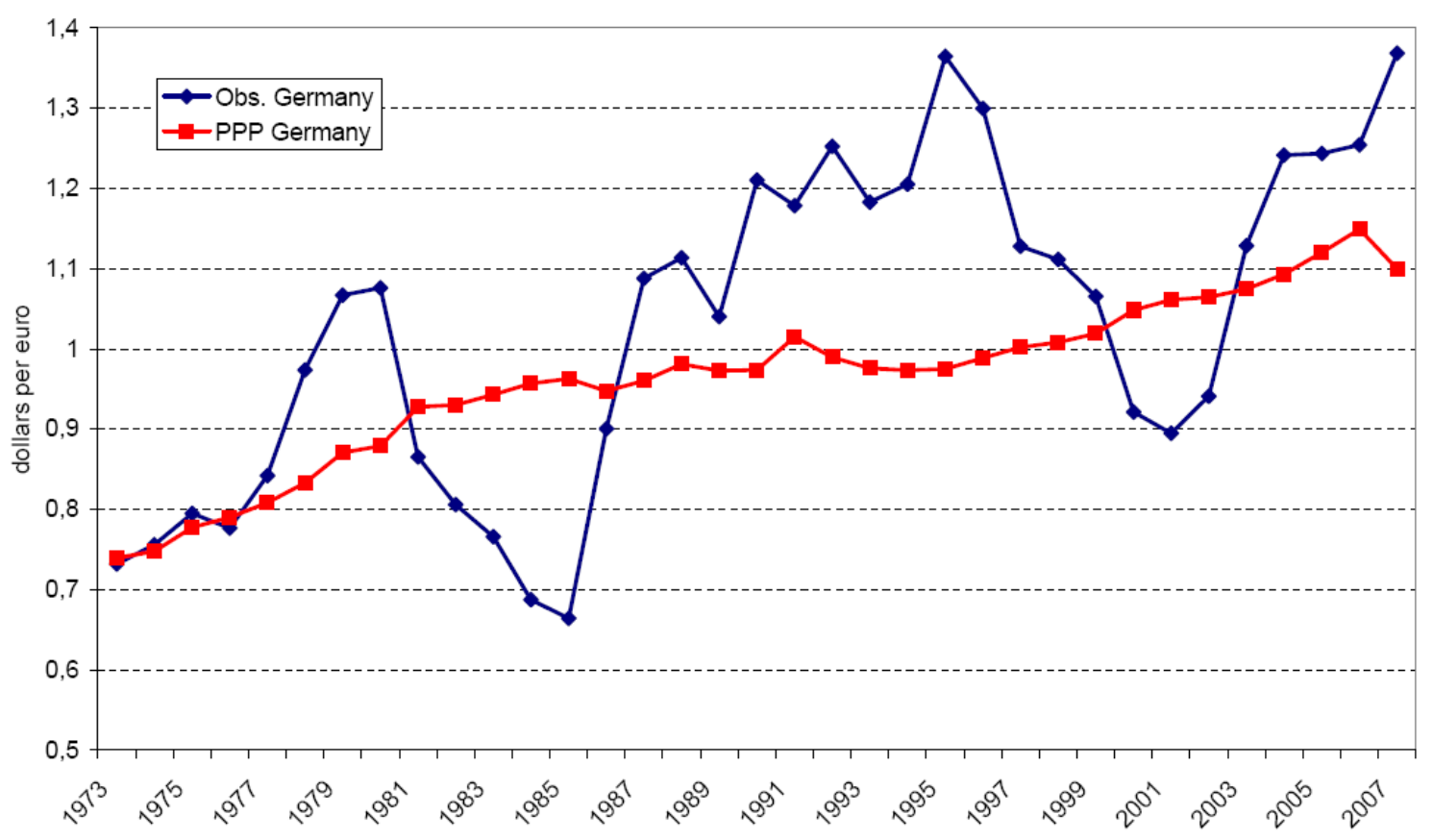

Source: CEPII CHELEM Database 
TABLE 2

Estimated price elasticities by destination market, selected countries, big aircraft

\begin{tabular}{l|l|l|l}
\hline Country & Price elasticity & Country & Price elasticity \\
\hline Germany & 2.5 & Turkey & 9.5 \\
Japan & 2.7 & Hong-Kong & 9.9 \\
U.S.A. & 2.8 & U.K. & 11.5 \\
Singapore & 2.9 & Mexico & 12.0 \\
Canada & 4.5 & Brazil & 14.3 \\
Belgium-Lux. & 5.5 & Russia & $>20$ \\
Sweden & 6.1 & India, China & $>30$ \\
\hline
\end{tabular}

Source: BACI CEPII, authors' calculations. 
TABLE 2

Effects of a $10 \%$ appreciation of the euro

\begin{tabular}{l|l|l|l|l|l|l}
\hline Cross-price elasticity & \multicolumn{3}{|c|}{1.5} & \multicolumn{2}{c}{3} \\
\hline Price elasticity & 2 & 4 & $\mathbf{6}$ & 8 & 4 & 8 \\
\hline \% change in price in USD & 2.9 & 3.9 & $\mathbf{4 . 2}$ & 4.4 & 4.4 & 4.5 \\
A320 & 1.0 & 0.7 & $\mathbf{0 . 5}$ & 0.4 & 1.6 & 0.9 \\
B737 & & & & & & \\
\hline$\%$ change in output in volume & 4.2 & 14.5 & $\mathbf{2 4 . 6}$ & 35.0 & 12.5 & 33.7 \\
A320 & 2.2 & 2.9 & $\mathbf{3 . 2}$ & 3.3 & 6.6 & 6.8 \\
B737 & & & & & & \\
\hline \% change in operating profit in USD & 8.2 & 26.8 & $\mathbf{4 3 . 0}$ & 57.0 & 23.5 & 56.0 \\
A320 & 4.4 & 5.9 & $\mathbf{6 . 5}$ & 6.7 & 13.5 & 14.0 \\
B737 & 10 & 30 & $\mathbf{5 0}$ & 70 & 30 & 70 \\
A320 without price adjustment & & & & & & \\
\hline
\end{tabular}

Note: base case in bold. Source: Authors' calculations. 